\title{
STAGES OF GONADAL DEVELOPMENT AND MEAN LENGTH AT FIRST MATURITY OF WILD FEMALES OF WHITE SHRIMP (Litopenaeus schmitti - DECAPODA, PENAEIDAE) IN SOUTHERN BRAZIL
}

\author{
IRECE FARINA MACHADO ${ }^{1,2}$, LUIZ FELIPE CESTARI DUMONT ${ }^{1} \&$ FERNANDO D'INCAO ${ }^{1}$ \\ ${ }^{1}$ Universidade do Rio Grande (FURG)- Instituto de Oceanografia. Av. Itália, km 7, Caixa Postal 474, 96201-900 - Rio Grande, - RS - Brasil. \\ irecemachado@furg.br
}

\begin{abstract}
The stages of gonadal development for the female of white shrimp (Litopenaeus schmitti (Burkenroad, 1936)) were characterized based on histological analysis. Four stages (immature, developing, ripe and spawned) were determined according to the structure and arrangement of cells in the ovary. Each stage corresponds macroscopically to a characteristic color, except stages I (immature) and IV (spawned), in which colors are very similar and can be distinguished only microscopically. The chromatic scale varies from white/translucent (stage I), gray/green (developing), dark green to black (ripe). The mean size of cells was $54.01 \mu \mathrm{m}( \pm 3.5)$ (stage I), $136.80 \mu \mathrm{m}( \pm 8.8)$ (stage II) and $199.80 \mu \mathrm{m}( \pm 6.4)$ (stage III). The size frequency of cells was polymodal, and different cell stages were observed in ripe ovary, suggesting the occurrence of multiple spawning. The smallest ripe female measured $146 \mathrm{~mm}$ and the largest $180 \mathrm{~mm}$ of the total length. Estimated mean length at first maturity was $152 \mathrm{~mm}$ and the length at which $100 \%$ of females are mature is $170 \mathrm{~mm}$.
\end{abstract}

KEY WORDS: Litopenaeus schmitti, shrimp, reproduction, gonadal histology, length at first maturity

\section{RESUMO}

Os estágios de desenvolvimento das gônadas das fêmeas do camarão-branco (Litopenaeus schmitti (Burkenroad,1936)) foram caracterizadas por análise histológica. Quatro estágios (imaturo, em desenvolvimento, maduro e desovado) foram determinados de acordo a estrutura e arranjo das células no ovário. Cada estágio corresponde, microscopicamente, a uma cor característica, exceto nos estágios I (imaturo) e IV (desovado) nos quais as cores são muito similares e podem ser distinguidas apenas histologicamente. A escala cromática varia do branco/translúcido (estágio I), cinza/verde (em desenvolvimento), verde escuro a preto (maduro). O tamanho médio das células foi $54,01 \mu \mathrm{m}( \pm 3,5)$ (estagio I), 136,80 $\mu \mathrm{m}( \pm 8,8)$ (estágio II) e 199,80 $\mu \mathrm{m}( \pm 6,4)$ (estágio III). A distribuição de frequência do tamanho das células foi polimodal, e diferentes estágios celulares foram observados nos ovários maduros, sugerindo a ocorrência de desovas múltiplas. A menor fêmea madura mediu $152 \mathrm{~mm}$ e o comprimento em que $100 \%$ das fêmeas estavam maduras foi $170 \mathrm{~mm}$.

PALAVRAS CHAVE: Litopenaeus schmitti, camarão-branco, reprodução, histologia gonadal, comprimento de primeira maturação

\section{INTRODUCTION}

Litopenaeus schmitti (Burkenroad, 1936) is known as the white shrimp, occurring in Western Atlantic from Antilles, Virgin Islands and Cuba $\left(23^{\circ}\right.$ $30^{\prime} \mathrm{N}$ ), through Honduras, Western Coast of Caribbean, Venezuela and along the Atlantic coast of South America until the northern border of Rio Grande do Sul State $\left(29^{\circ} 45^{\circ}\right.$ S) (Pérez-Farfante,1970a,b). This species has the typical penaeid shape and it is usually found from littoral to 30 meters depth, despite the fact that occasional occurrences have been reported for 50 meters (D'Incao, 1995).

As well as the pink shrimp (Farfantepenaeus spp.), this species is largely dependent on the estuarine regions to complete its life cycle (Neiva \& Wise, 1963; Garcia \& Le Reste, 1981; D'Incao, 1999), showing continuous reproduction that usually presents two seasonal peaks (Coelho \& Santos, 1995b). Thus, fishing effort applied over the both phases of its life cycle may lead to the collapse of either, small scale, or industrial exploitation of these resources (Garcia \& Le Reste,1987; D'Incao,1991).
The main target, of penaeid fishery in Brazil, used to be the pink shrimps (Farfantepenaeus paulensis e $F$. brasiliensis). The reduction of yields, observed in commercial fleet, resulted in a multi-target activity, in such a way that other penaeid species became commercially important (Valentini et al., 1991; D'Incao et al., 2002). Among the recent exploited shrimp species, the white shrimp is one of the most valuable ones in Southern and Southeastern Brazil. As a result, the impact of this activity over the white shrimp was also altered and the need for novel population assessment is noticeable.

The comparison of macroscopic traits to the features observed in histological sections allows creating a practical reference table to classify ovary development in laboratory routines, to be used in ecological and fishery investigations. This technique has been proved to be useful in many penaeid species, such as $F$. paulensis and $F$. brasiliensis (Peixoto et al., 2003; Dumont et al., 2007), A. longinaris, (Dumont \& D'Incao, 2004), Penaeus indicus (Castille \& Lawrence, 1991; Quinitio \& Millamena, 1992), Penaeus kerathurus (Medina et al., 
1996; Vogt et al., 1989) and Penaeus monodon (Palacios et al., 1999).

Size or age at first maturity is a valuable reference point to properly manage a shrimp stock, since reproduction is the phenomenon responsible for the stock renewal (Coelho \& Santos, 1995; Castilho et al., 2007). Therefore, ovarian maturation stages, as well as the mean length at first maturity are vital to investigate reproductive dynamics of $L$. schmitti. Thus, the aim of this investigation is to create an accurate chromatic scale to classify ovary development of the white shrimp from Southern Brazil based on histological sections and to estimate the size at first maturity.

\section{MATERIAL AND METHODS}

Sampling was performed during autumn and late spring to assure that females participating on the most important breeding events were captured, since most of subtropical penaeid species are reproducing during these periods (Gulland \& Rotschild, 1981). Fishing gear used was an otter trawl, and investigation cruises were conducted by IBAMA onboard of the N/P Soloncy Moura (Instituto Brasileiro do Meio Ambiente e dos Recursos Hídricos Renováveis, IBAMA - CEPSUL). A total of 76 trawl fishing operations, with duration of 30 minutes each, was performed in depths ranging from 10 to 100 meters in the surrounding area of Babitonga, Bay, Santa Catarina State, Brazil $\left(26^{\circ} \mathrm{S}\right)$ (Figure 1). Each station was sampled during daylight and night since spawning occurs mainly during the dusk and the night.

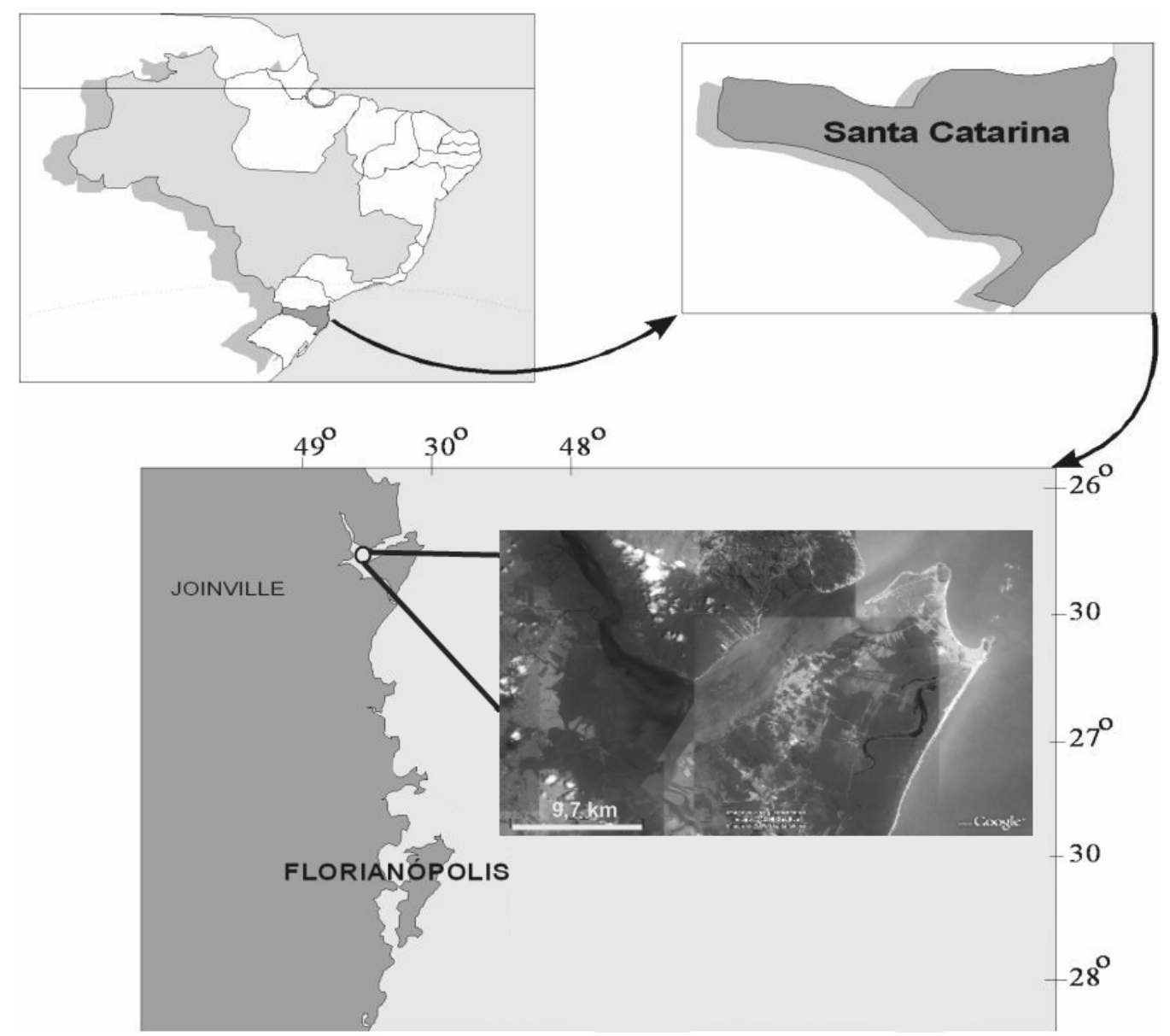

Figure 1. Study area in Southern Brazil, highlighting the Babitonga Bay and the adjacent area where sampling took place.

The reliability of macroscopic scale was validated by performing histological techniques that provided valuable information on the relationship

between color and shape of the ovaries and the cell traits. The ovaries were preferred due to larger size and easier macroscopic identification than the testes. 
Additionally, the reproduction process occurring in a population largely depends on the females that are usually used as an indicative of this population process.

Total length (TL) was measured from the tip of rostrum to the end of telson. At least 15 ovaries, from each development stage, were sampled. A sample of ovarian tissue was collected from anterior part of gonad for histological sectioning since homogeneous development along the ovary has been reported for a similar species (Peixoto et al., 2003). Shape and color (Pantone, 1999) of ovaries were digitally recorded under the approximated same quantity of light, to establish a macroscopic classification validated by subsequent histological sections. To define the ovary color accurately, an automated tool was used, comparing the predominant ovary color to a Pantone's reference table. This tool samples a square of $12 \times 12$ pixels and provides the mean reference color obtained within this area (Dumont et al., 2007). Tissue was fixed in Formalin $(10 \%)$, paraffin embedded, sectioned $(6 \mu \mathrm{m})$ and Hematoxilin-Eosin stained. At least 30 oocytes diameters per female were measured and a One-Way ANOVA and Tukey's test were applied to verify significant differences $(p<0.05)$ among mean oocyte size grouped according to development stage (Zar, 1984).

Mean size at first maturity (LM) was considered as the size class interval (1 $\mathrm{mm}$ interval) in which frequency of ripe females is $50 \%$ (King, 1997). Frequency of ripe females was fitted to the logistic model by an automated least square procedure, in such a way that:

$$
P=1 /\left[1+\exp ^{(-r(C L 1-L M))}\right],
$$

Where $P$ is the percentage of ripe females in a given length class, $r$ is the logistic curve slope, $C L 1$ is the upper limit of carapace size interval and LM is the mean length at first maturity.

\section{RESULTS}

Considerable differences in color and shape of the ovaries were observed for $L$. schmitti in the wild. Four different stages were observed, named stage I (immature), stage II (developing), stage III (ripe) and stage IV (spent).

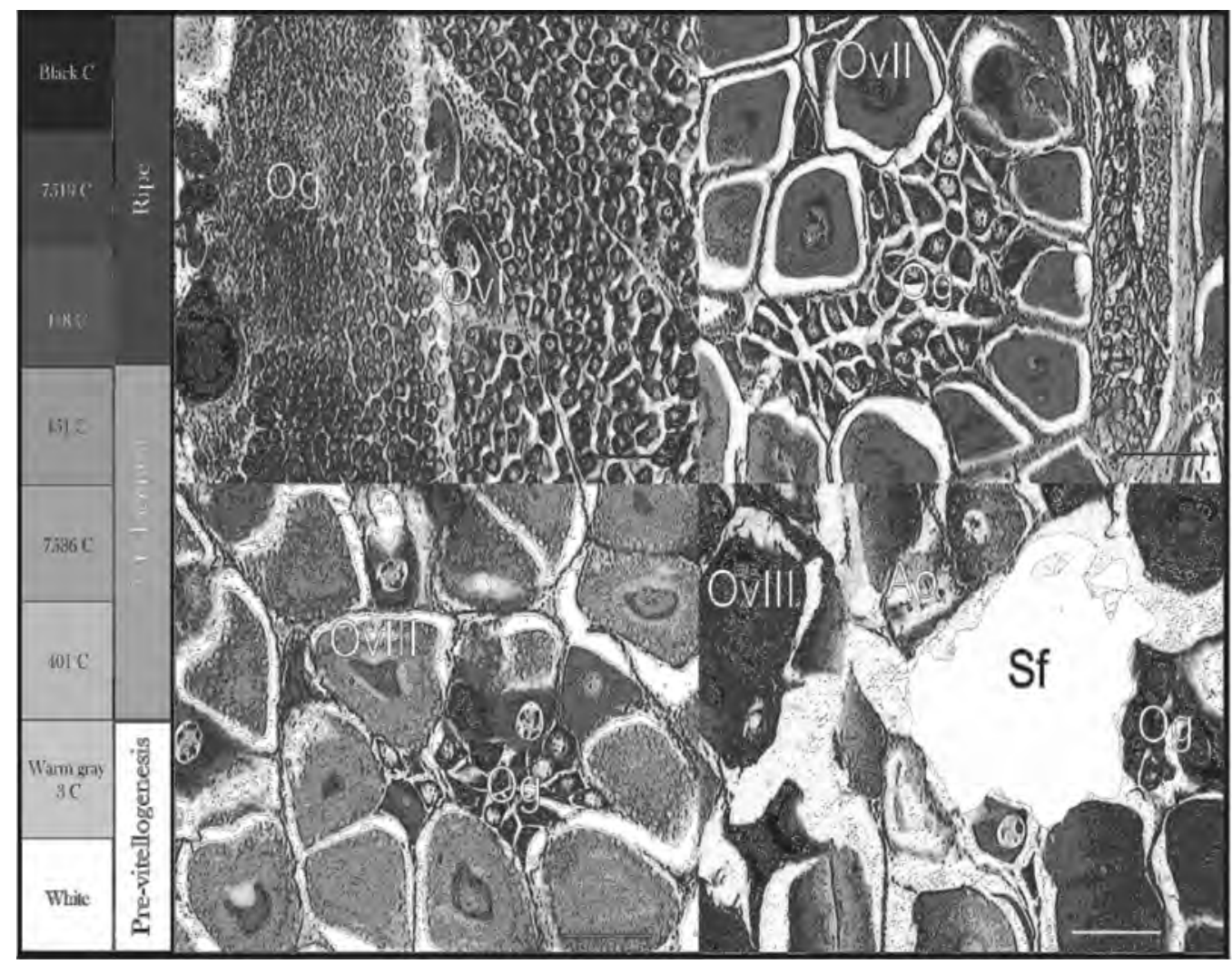

Figure 2. Litopenaeus schmitti. Histological sections of the ovary. A. stage I (immature); B. stage II (developing); C. stage III (ripe); D. stage IV (spent). Og= oogonies; Ovl= pre-vitellogenic oocyte; Ovll= vitellogenic oocyte; Ovlll= mature oocyte; $\mathrm{Sf}=$ spent follicle. Scale $=100 \mu \mathrm{m}$. 
Stage I (immature): Ovary is white translucent to warm gray $(3 C)$ and is difficult to distinguish it through the carapace. Cephalotoracic lobes of the ovary are not developed and are reduced to the posterodorsal part of the stomach. The abdominal region of the gonad is reduced and usually does not extend further than third abdominal somite. In terms of cell traits, only the previtellogenic oocytes (OVI) and oogonies (OO) were observed during this stage. These cells are small $(54.01 \mathrm{~mm} \pm 3.54)$ and the absence of yolk production is confirmed by the affinity of the cytoplasm for the hematoxilin, suggesting basophily.
Stage II (developing): Filling most of the abdominal cavity, the ovary is clearly better developed, when compared to stage I. Two longitudinal and parallel lobes are observed along the abdominal portion of the gonad. In the cephalic region, the ovary covers part of stomach. Now, the ovary can be observed through carapace and color ranges from gray to green (417C-451C). During this stage, developing oocytes (OVII) significantly increase in size $(136.8 \mathrm{~mm} \pm 8.8$ ), the start of vitellogenesis is observed indicated by eosin stained oocytes in histological sections.

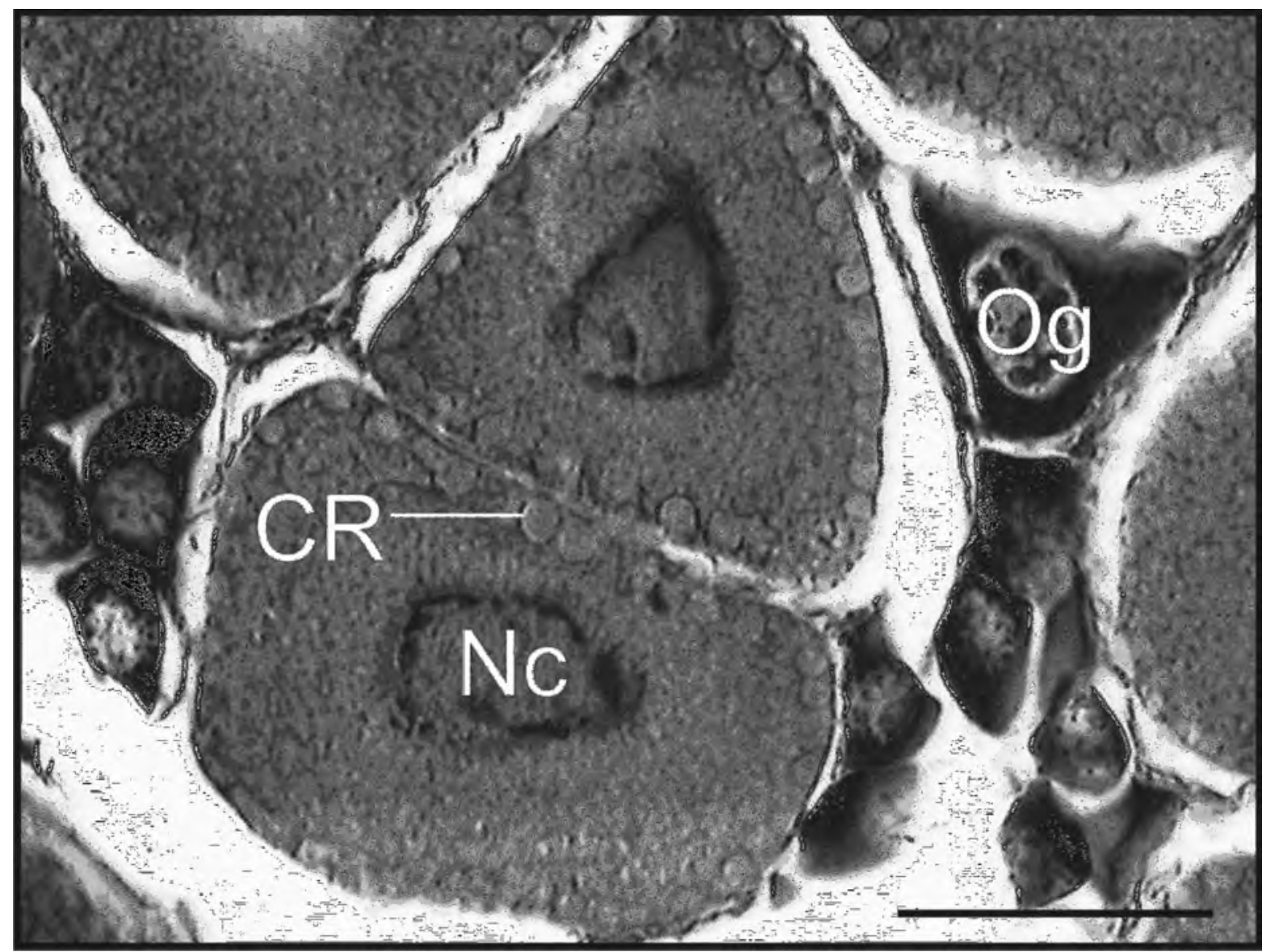

Figure 3. Litopenaeus schmitti. Histological section of the ovary showing the final maturation structures for penaeid shrimps, the cortical rods (CR). Scale $=100 \mu \mathrm{m}$.

Stage III (ripe): Ovary fills the entire abdominal cavity and presents colors ranging from dark green to black (418C-BlackC). Cephalotoracic portion of ovary covers the entire stomach and presents several developed lobes. Microscopically, ripe cells (OVIII) are larger (199.8 $\mathrm{mm} \pm 6.4$ ) and present cortical rods $(\mathrm{CR})$, a structural modification that indicates final maturation of oocytes in most of penaeid species.

Stage IV (spent): The spent stage is usually similar to immature, even though it is very difficult to distinguish them macroscopically. However, spent ovary can be identified microscopically by the presence of reabsorbing cells or atretic oocytes (AO). During this stage, some ripe and developing oocytes 
remain in ovarian follicle indicating that partial spawning may occur for this species. Size overlapping of oocytes was recorded between different developing stages however significant differences $(p<0.005)$ related to mean oocyte diameter were observed
(Table I). Visual analysis of size frequency of oocytes showed a polymodal pattern, with two peaks for immature oocytes and three for developing and ripe (Figure 4).

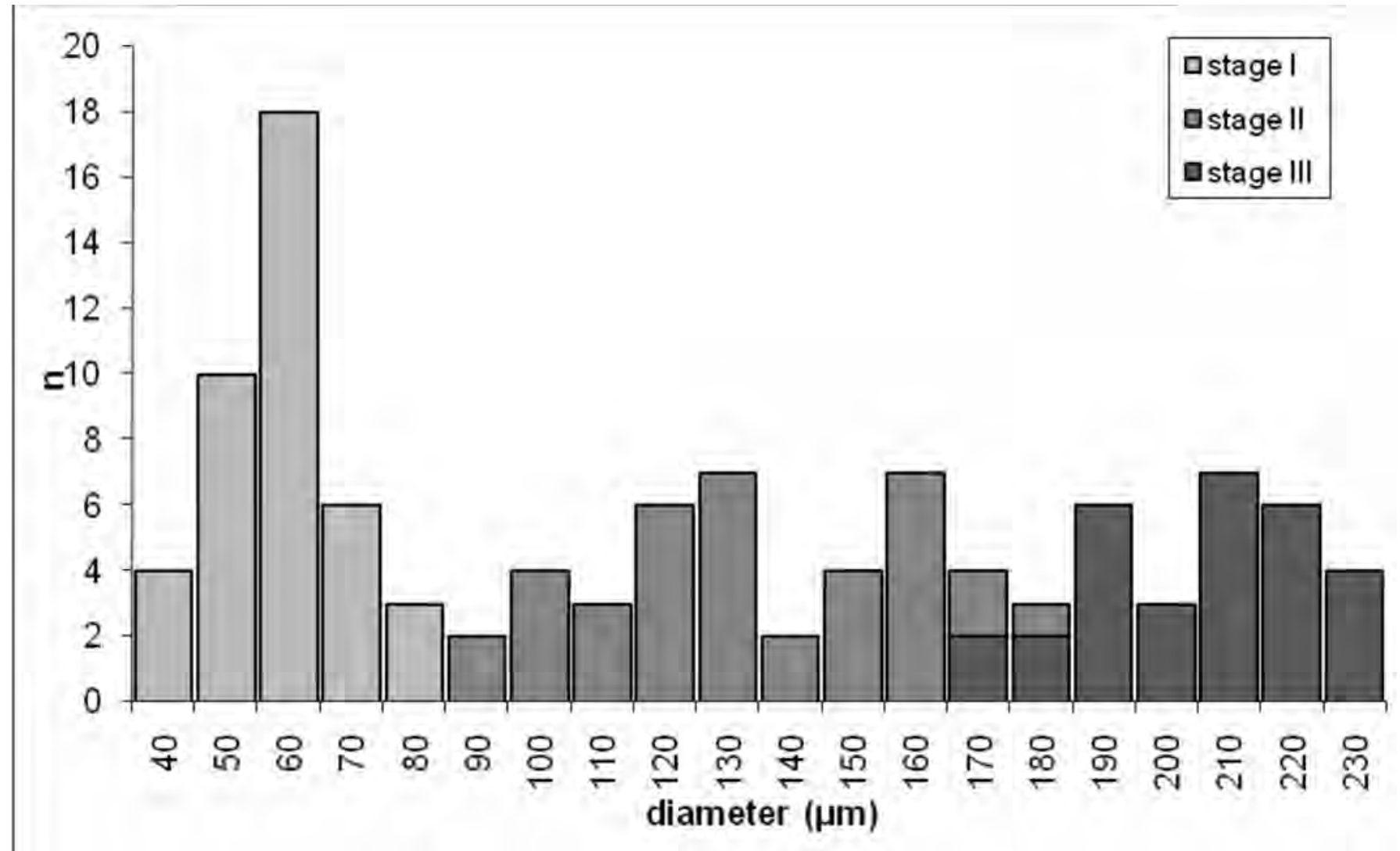

Figure 4. Litopenaeus schmitti. Size frequency of cell diameter according to development stage of ovaries.

Table I. Statistic summary of oocyte size analysis, containing number of oocytes measured (N) for each development stage, mean values $(X)$, confidence intervals $(\mathrm{Cl} \pm 95 \%)$ and size range (minimum and maximum).

\begin{tabular}{lccccc}
\hline $\mathbf{N}$ & mean & \multicolumn{2}{c}{ Cl } & min & $\max$ \\
\hline 42 & 54.5 & $-95 \%$ & $95 \%$ & & \\
\hline 46 & 136.8 & 12.0 & 58.0 & 35.0 & 93.2 \\
30 & 199.8 & 193.4 & 145.6 & 80.8 & 187.9 \\
\hline
\end{tabular}

The smallest ripe female measured $146 \mathrm{~mm}$ $(\mathrm{TL})$ and the largest $180 \mathrm{~mm}(\mathrm{TL})$. Estimated mean length at first maturity (LM) was $152 \mathrm{~mm}(\mathrm{TL})$ (Figure
5, Table II) and the length at which $100 \%$ of females are mature is $170 \mathrm{~mm}(\mathrm{TL})$. 


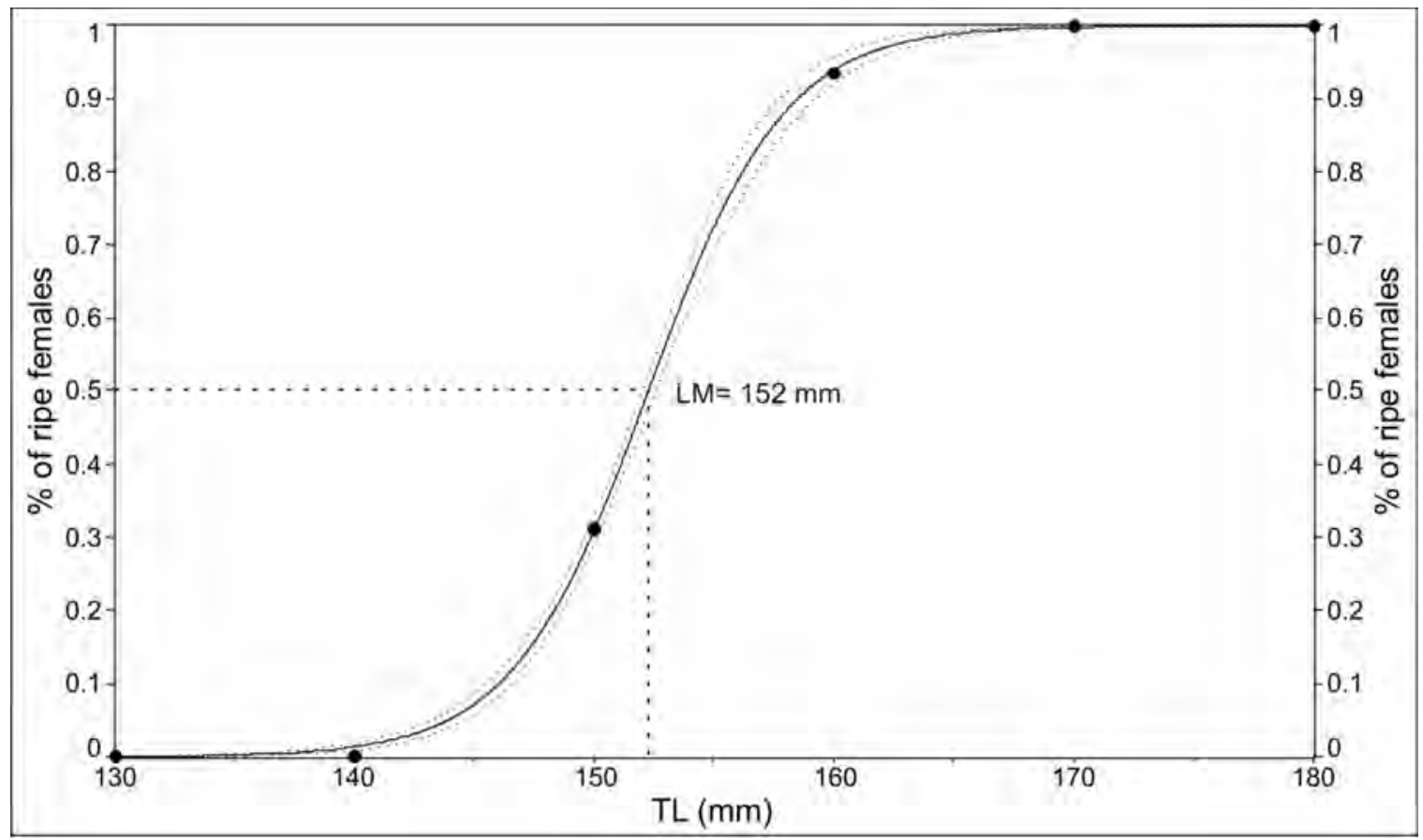

Figure 5. Litopenaeus schmitti. Logistic curve of ovarian maturation.

Table II. Summary of fit obtained from logistic model, containing the parameter fit (Parm), the value estimated (Value), the standard error (se), the $t$ value ( $t$ ), the confidence limits to $95 \%$ of significance as well as the $p$ value (limit of significance adopted was $p<0.005$ ).

\begin{tabular}{lllllll}
\hline Parm & Value & se & $\mathrm{t}$ & $\mathrm{Cl}(95 \%)$ & & $\mathrm{p}$ \\
\hline $\mathrm{r}$ & 0.35 & 0.01 & 297 & 0.32 & 0.38 & 0.00001 \\
LM & 152 & 0.10 & 1.487 & 151 & 152.5 & 0.00000 \\
\hline
\end{tabular}

\section{DISCUSSION}

The comparison of macroscopic traits to the features observed in histological sections allowed to create a practical reference table to classify ovary development in laboratory routines to be used in ecological and fishery investigations. However, slightly different colors were attributed to each stage, when compared to the previous investigation for this species. The ovary of $L$. schmitti presented a thin layer covering the entire organ, which may have caused distortion in the color reference when analyzed without dissecting. Therefore, unlike most of penaeids, we strongly recommend the dissection of the ovaries obtained from this species to classify the development stage of maturity, since the layer covering it, may represent a source of misinterpretation. In contrast, the microscopic analysis prevents the common mistakes performed in ovary classification of penaeids, including the errors associated to the presence of color pigments that are not directly associated to the ovary development.

The ovary development of penaeid shrimps is usually divided in 5 different stages, named immature, developing, incipient, ripe and spent (Vogt et al., 1989; Castille \& Lawrence, 1991; Tan-Fermin, 1991; Medina et al., 1996; Quintero \& Garcia, 1998; Palacios et al., 1999). Recently, the investigations intending to classify the ovaries for fishery management purposes have suggested the simplification of the development stages, reducing it to only 4, named immature, developing, ripe and spent (Peixoto et al., 2003; Dumont et al., 2007). It does happen due to high similarity between developing and incipient maturity stages, which show similar stage of cell development, but slightly different organization. Nonetheless, the indication of final maturation is given by the presence of the cortical rods, since these structures are important during egg activation process, and help to avoid polyspermy as well as to 
create a microenvironment suitable for egg development (Clark et al., 1980).

Once the ovary development is well determined, a reliable classification of the ovaries allows estimating the mean length at first maturity (LM). This parameter has been used as a reference point to manage exploited penaeid stocks and may indicate ecological process if monitored through time and/or space. When the LM estimated for this species in Southern Brazil is compared to Southeastern Brazil (SP) very similar values were recorded (158 $\mathrm{mm} \mathrm{CL}$ ), suggesting that the same LM value may be used as a reference point for this species in Southern and Southeastern Brazil. Slightly lower values were estimated for the Gulf of Venezuela, for a population inhabiting warmer waters, which is coherent with the general pattern of latitudinal variation in the size at first maturity reported for penaeids (Castilho et al., 2007).

\section{CITED LITERATURE}

CASTILHO AL, RC COSTA, A FRANSOZO, EE BOSCHI. 2007. Reproductive pattern of the South American endemic shrimp Artemesia longinaris (Decapoda, Penaeidae), off the coast of São Paulo state, Brazil. Rev. Biol. Trop. 55:39-48.

CASTILLE FL. \& AL LAWRENCE. 1991. Reproductive studies concerning natural shrimp populations: a description of changes in size and biochemical compositions of the gonads and digestive glands in penaeid shrimps. In: DE LOACH, P. F.; DOUGHERTY, W. J. \& DAVIDSON, M. A. eds. Front. of Shrimp Res. Amsterdam, Elsevier. v.22, p.17-32.

CLARK JR. WH, JW LYNN, HO PERSYO. 1980. Morphology of the cortical reaction in the eggs of Penaeus aztecus. Biol. Bull., 158, 175- 186.

COELHO PA \& MCF SANTOS. 1995. Época de reproduçao dos camarões: Penaeus schmitti Burkenroad 1936 e Penaeus subtilis Perez-Farfante, 1967 (Crustacea, Decapoda, Penaeidae) na região de Tamandaré PE. Bol. Técn. Cient. CEPENE, 1: 157-170.

D'INCAO F. 1991. Pesca e biologia de Penaeus paulensis na Lagoa dos Patos, RS. Atlântica, 13 (1): 159-169.

D'INCAO, F. 1995. Taxonomia, padrões distribucionais e ecológicos dos Dendrobranchiata (Crustacea, Decapoda) Do Brasil e Atlântico Ocidental. Tese de Doutorado, Pós Graduação em Ciências Biológicas, Zoologia, Universidade Federal do Paraná, 365p.

D'INCAO, F. 1999. Os camarões do Rio Grande do Sul, Sub Ordem Dendrobranchiata (camarões marinhos). Editora da Universidade, UFRGS: 271-299.

D'INCAO F, H VALENTINI, LF RODRIGUES. 2002. Avaliação da pesca de camarões nas regiões Sudeste e Sul do Brasil. 19651999. Atlântica, 24(2): 49-62.

DUMONT LFC \& F D'INCAO. 2004. Estágios de desenvolvimento gonadal de fêmeas do camarão-barbaruça (Artemesia longinaris - Decapoda: Penaeidae). Iheringia (Zool.), Porto Alegre, 94(4):389-393.
DUMONT LFC, F D'INCAO, RA SANTOS, S MALUCHE, LF RODRIGUES. 2007. Ovarian development of wild pink prawn (Farfantepenaeus paulensis) females in northern coast of Santa Catarina State, Brazil. Nauplius 15(2): 65-71.

GARCIA S \& L Le RESTE. 1981. Life cicles, dynamics, exploitation and management of coast penaeid shrimp stocks. FAO Fish. Tech. Pap. Roma, 203: 1-215.

GARCIA S \& L Le RESTE. 1987. Ciclos vitales, dinamica, explotación y ordenación de las poblaciones de camarones peneidos costeros. Roma: Organización de las Naciones Unidas para la Agricultura y la Alimentación. FAO Sér. Doc. Téc. Pesca, 203: 180 p.

GULLAND JA. \& ROTHSCHILD, BJ. 1981. Penaeid shrimps: their biology and management. Fishing News Books. Farnham. Surrey. England.

KING, MG. 1997. Fisheries biology, assesment and management. Fishing news books. Osney Mead, Oxford, England., pp. 341.

MEDINA A, Y VILA, G MOURENTE, A RODRíGUEZ. 1996. A comparative study of the ovarian development in wild and pondreared shrimp, penaeus kerathurus (Forslkal, 1775). Aquaculture 148: 63-75.

NEIVA GS \& JP WISE. 1963.The biology and fishery of the seabob-shrimp of Santos Bay, Brazil. Proc. Gulf. Caribb.Fish. Inst.,16: 131-139.

PANTONE. 1999. Pantone Professional Color System. 14th ed. New Jersey, Carlstad. 260p.

PALACIOS E, C RODRIGUES-JARAMILLO \& IS RACOTTA. 1999. Comparison of ovary histology between different-sized wild and pond-reared shrimp Litopenaeus vannamei (=Penaeus vannameI). Invertebr. Reprod. Dev., 35 (3): 251-259.

PEIXOTO S, RO CAVALLI, F D'INCAO, ÂM MILACH \& W WASIELESKY. 2003. Ovarian maturation of wild Farfantepenaeus paulensis in relation to histological and visual changes. Aquacult. Res., 34: 1255-1260.

PEREZ-FARFANTE I. 1970a. Sinopsis de datos biologicos sobre el camarón blanco Penaeus schmitti Burkenroad, 1936. FAO Fish. Rep. 57:1417- 1438.

PEREZ-FARFANTE I. 1970b. Claves ilustradas para la identificación de los camarones comerciales de la America Latina. Inst. Nac. Invest. Pesq., Serie Divulgacion, Instructivo, 3: 50p.

QUINITIO ET \& OM MILLAMENA. 1992. Ovarian changes and female-specific protein levels during sexual maturation of the white shrimp Penaeus indicus. Isr. J. of Aquacult./Bamidgeh, 44(1):7-12.

QUINTERO MES \& A GARCIA. 1998. Stages of gonadal developent in the spotted pink shrimp Penaeus brasiliensis. $J$. of Crust. Biol., 18 (4): 680-685.

TAN-FERMIN JD. 1991. Effects of unilateral eyestalk ablation on ovarian histology and oocyte size frequency of wild and pondreared Penaeus monodon (Fabricius). broodstock. Aquaculture, 93: 77-86.

VALENTINI H, F D'INCAO, LF RODRIGUES, JE REBELO-NETO, E RAHN. 1991. Análise da pesca do camarão-rosa (Penaeus paulensis e Penaeus brasiliensis) nas regiões e sul do Brasil. Atlântica, 13(1): 143-157.

VOGT, G.; QUINITIO, ET \& PASCUAL, FP. 1989. Interaction of the midgut gland and the ovary in vitellogenesis and consequences for the breeding success: a comparison of unablated and ablated spawners of Penaeus monodon. In: DE PAUW, J. N.; ACKEFORS, H.; WILKINS, N. E. eds. Aquaculture. A biotechnology in progress. Bredene, European Aquaculture Society. p.581-592.

ZAR, TH. 1984. Biostatistical analysis. Prentice Hall Inc., Englewood Cliffs. pp. 718. 
IRECE FARINA MACHADO, LUIZ FELIPE CESTARI DUMONT \& FERNANDO D'INCAO 